\title{
GLOBALIZACIJOS RAIŠKA EUROPOS PEREINAMOSIOS EKONOMIKOS ŠALIŲ VERSLO APLINKAI: YPATUMAI IR POVEIKIO VEIKSNIAI
}

\author{
Laimona Šliburyte் ${ }^{1}$, Rūta Masteikiené ${ }^{2}$ \\ ${ }^{1}$ Kaunas University of Technology, Lithuania, laimona.sliburyte@ktu.lt \\ ${ }^{2}$ Kaunas University of Technology, Lithuania, ruta.masteikiene@ktu.lt \\ cross ref http://dx.doi.org/10.5755/i01.em.17.4.3010
}

\begin{abstract}
This article is meant to be an analysis of the peculiarities of globalization process and its impact on the business environment of European countries in transition. It thoroughly analyses various definitions of globalization and presumptions of their origin, driving forces of the process, future potential, qualities, advantages and disadvantages in the context of European transition economies. The influence of globalization process on the European transition economies could be divided into the following aspects: the overall growth in mobility and accessibility, the rapid decrease of mobility (exchange) barriers, the loss of importance of geographical location and the rise in IT hegemony, the increase of time value, the unprecedented spread and velocity of the process. The authors of this article analyse each impact separately and present opinions of various authors on the particular impacts' implications and level of exposure. European transition economies, peculiarities of their business environments, the effects of transition process, their progress in worldwide integration and relation to globalization phenomenon are also subject to analysis in this paper.

Keywords: globalization, transition economies, business environment.

JEL Classification: F15, P27, E20.
\end{abstract}

\section{Ivadas}

Nors daugybė pasaulio mokslininkų ir tyrèjų iki šiol nesutaria dèl vieningos globalizacijos sampratos, tačiau visuotinai sutariama, kad šio proceso plètojimasis, gilejimas ir greitëjimas be išimčiu veikia visus ekonomikos sektorius. Kaip savo darbuose argumentuoja (Dicken, 2009; Wolf, 2004; Held ir kt., 2002; Bhagwati, 2007; Castells, 2005; Stiglitz, 2002) globalizacija sąlygoja esminius pokyčius bei kuria iš esmès naują verslo aplinką, kurioje ekonomikos subjektai turi iš naujo priimti svarbius, jų verslą lemiančius sprendimus.

Šios temos aktualumą lemia tai, kad nors Europos pereinamosios ekonomikos šalys (tarp jų ir Lietuva) yra plačiai atsivėrusios regioninei integracijai ir globalizacijai, tačiau mokslo darbų, nagrinėjančių šių procesų poveikị ekonomikos subjektų verslo aplinkai, stokojama.

Śiame straipsnyje, nagrinèjami globalizacijos procesas, jo koncepcijos, skatinamosios jègos, potencialas, fenomeno savybès, privalumai bei trūkumai, poveikio veiksniai Europos pereinamosios ekonomikos šalių kontekste bei šių šalių verslo aplinkos ypatumai ir jų sąsajos su globalizacijos procesu. Atlikta analizė atskleidè, jog dauguma Europos pereinamosios ekonomikos šalių perèjimo procese yra padariusios pažangą tinkamos verslo aplinkos kūrime pereinamuoju laikotarpiu, tačiau yra sričių, kurios dar atsilieka ir reikia dèti nemažai pastangų, kad pasiekti išsivysčiusių valstybių lygị.

Europos pereinamosios ekonomikos šalių vyriausybėms vykdant verslo aplinkos gerinimo programas, šalys igytų daugiau galimybių efektyviai išnaudoti globalizacijos proceso teikiamas ekonomines ir kt. galimybes, bei išvengtų (ar galètų suvaldyti) atnešamas grèsmes.

Šio tyrimo tikslas - išanalizuoti esminius globalizacijos ypatumus bei poveikio veiksnius Europos pereinamosios ekonomikos šaliu verslo aplinkai.

Pagrindiniai tyrimo uždaviniai:

- išanalizuoti ịvairių autorių pateikiamas skirtingas globalizacijos koncepcijas ir apibrèžties kilmès prielaidas;

- išanalizuoti globalizacijos skatinamąsias jègas, potencialą, savybes, privalumus bei trūkumus Europos pereinamosios ekonomikos šalių kontekste;

- atlikti esminiu globalizacijos poveikio veiksnių Europos pereinamosios ekonomikos šalių verslo aplinkai analizę;

- išnagrinèti Europos pereinamosios ekonomikos šalių verslo aplinkos ypatumus.

Tyrimo problema: kaip globalizacijos procesas veikia Europos pereinamosios ekonomikos šaliu verslo aplinką?

Tyrimo objektas - globalizacijos procesas, poveikio veiksniai Europos pereinamosios ekonomikos šalių verslo aplinkai. 
Tyrimo metodai. Analizuojant globalizacijos ypatumus bei poveikio veiksnius Europos pereinamosios ekonomikos šalių verslo aplinkai buvo naudojami šie bendramoksliniai tyrimo metodai: sisteminè, lyginamoji ir loginè mokslinès literatūros analizè.

\section{Globalizacijos samprata ir apibrèžties kilmès prielaidos}

Globalizacija šiuolaikiniame Vakarų socialiniame moksle ir žiniasklaidoje tapo vienu iš dažniausiai vartojamų terminų. Kaip teigia Held ir McGrew, (2002), globalizacijos traktuotès ir su ja susijusios temos pakeitè anksčiau madingą postmodernizmo sąvoką ir postmodernistinę analizę. Nedaug dabartinio pasaulio procesų yra suprantama ir vertinama taip skirtingai kaip globalizacija, nors neabejojama, kad tai objektyvus tautų, bendruomenių, individų gyvenimą veikiantis, o ateityje dar labiau veiksiantis reiškinys (Kuzmickas, 2004).

Terminas globalizacija kildinamas iš žodžio "global" (liet. pasaulinis, visuotinis). Žodis global skirtingose kalbose gali įgyti skirtingas reikšmes, bet bendriausia jo reikšmė yra erdvinė geometrinè figūra. Anot Altman (2009), terminas global reiškia „visuotinai apsiimtą“. Tokią prasmę žodžiui global priskiria daugelis Vakaru Europos kalbų. Be to, šis žodis prancūziškai reiškia „vienarūšiškumą“. Taigi bendrai globalizacija reiškia tiek ,vienarūšiškumą“, tiek ,visuotinumą““.

Mokslininkai nesutaria, kada globalizacijos terminas buvo pirmą kartą paminètas šiuolaikine jo prasme. Nors pačio globalizacijos termino, taip kaip jis yra traktuojamas šiuolaikinèje mokslinèje diskusijoje, kilmè siekia net XVII amžių, vis dèl to šis žodis yra labiau grindžiamas terminu ,globalinis telekomunikaciju tinklas“, kurị savo knygoje „Komunikacijos tyrinejjimai“ panaudojo kanadietis sociologijos profesorius M. McLuhan. Anot Ritzer, 2010), globalizacijos terminas pirmą kartą buvo pradètas vartoti apie 1980 m. JAV - Harvardo, Stanfordo ir Kolumbijos koledžuose ir labai greitai išpopuliarėjo tarp šių aukštuju mokyklų akademinių sluoksnių. Globalizacijos koncepcija imta naudoti nepriklausomai keliose akademinèse srityse. Sociologijos moksle globalumą pradėjo interpretuoti mokslininkas Robertson (1983). Beveik tuo pat metu Harvardo verslo mokyklos profesorius Lewitt (1983) ėmè tirti rinkų globalizaciją. Globalios tarpusavio priklausomybės aspektai pradèti nagrinèti mokslininkų (Rosenau, 1980), o kiek vèliau ir (Maghroori, Ramberg, 1982).

Globalizacijos sąvokos prasmę $1990 \mathrm{~m}$. labai praplètė autorius Ohmae savo knygoje „Pasaulis be sienų" (angl. "The Bordless World"). Autoriai (Bauman, 2008; Klinger, 2010) teigia, kad globalizacijos formavimosi prielaidas ir tolesnio vystimosi prognozes pirmasis aprašė JAV verslininkas, buvęs ministras Ch. T. Russell, jau 1897 m. pavartodamas terminą "corporate giants" (korporaciniai gigantai ${ }^{1}$ ).

Šiuo metu pastebima mokslinių straipsnių, publikacijų, nagrinėjančių globalizacijos problematiką, lavina. Ivairių mokslo sričių atstovai (daugiausia ekonomikos, sociologijos ir antropologijos) imasi nagrinèti globalizacijos problematiką. Autorius Guillen (2000) pastebi, jog labiausiai globalizacijos problematikos imasi įvairių socialinių mokslų atstovai, kurie daugiausia apibendrina kitų autorių darbus. Šioje srityje ypač pasigendama mokslinių rezultatų, paremtų empiriniais tyrimais. Tačiau, anot Gylio (2008), „publikacijų gausa nebūtinai reiškia, kad tema deramai ištirta, rezultatai brandūs, argumentai patikimi. Tyrèjai, žurnalistai, politikai nesutaria ir laisvai, subjektyviai interpretuoja daugelį pasaulinių reiškinių, o ypač globalizaciją. Dėl to kyla rimtų visų šių žmonių komunikacijos problemų, taip pat sunkumų, susijusių su tuo, jog esant didžiuliam nesusikalbejjimui vyksta savaiminių (reguliacinių) ir valdymo procesų deformacija, o tai galiausiai skatina tai, kas $<\ldots>$ yra vadinama antiekonomika.“

Yra daugybė nuomonių skirtumu mokslinejje ir politineje diskusijoje dèl globalizacijos termino vartojimo ir suvokimo. Su laiku globalizacijos apibrēžimų sparčiai daugèja - be ekonominių aspektų, daugèja kultūrinių, politinių, socialinių ir kitų šio fenomeno bruožų. Mokslininkas Najam (2007), teigia, jog tikriausiai yra tiek globalizaciją apibūdinančių apibréžimų, kiek autorių, rašančių šia tema. Easterly (2008) pabrèžia, jog moksliniuose darbuose „globalizacijos“ termino neapibrěžtumas yra vos ne „,nusikalstamas“.

Globalizacijos reiškinį daugybė mokslininkų visame pasaulyje tiria pasirinkdami skirtingus instrumentus, bei turi kartais net labai radikaliai skirtingus požiūrius ị globalizacijos:

1) sampratą;

${ }^{1}$ Šiais laikais korporaciniai gigantai vadinami multinacionalinėmis korporacijomis (angl. Multinational corporations $(M N E)$ ). Kol kas mokslinèje literatūroje lietuvių kalba galima rasti daugybę vertimo variantų: daugiašalès bendrovès, transnacionalinès kompanijos, tarptautinès korporacijos. Autorių nuomone, tiksliausiai sąvoką atspindètų pažodinis vertimas - multinacionalinès korporacijos. 
2) akseleratorius - skatinančiąsias jègas;

3) socialines, ekonomines bei politines pasekmes;

4) poveikị nacionalinėms valstybėms;

5) genezę.

Žemiau esančioje lentelèje, pateikiami gausiausiai mokslinėje literatūroje cituojami globalizacijos apibrěžimai, kuriuose atsispindi šio reiškinio daugiadimensiškumas, t.y. apimamos ekonominè, politinė, socialinè, kultūrinè, technologinè ir kt. dimensijos.

1 lentelè. Globalizacijos apibrèžimai

\begin{tabular}{|c|c|}
\hline Autorius ( & lizacijos apibrėžimas \\
\hline $\begin{array}{l}\text { Amerikos } \\
\text { gynybos } \\
\text { institutas (2009) }\end{array}$ & $\begin{array}{l}\text { Globalizacija - intensyvus ir nepertraukiamas prekių, paslaugų, kapitalo (arba pinigų), technologijų, } \\
\text { idejju, informacijos, kultūru ir tautu judejimas, kertantis valstybiu sienas. Pasak šio instituto, dèl } \\
\text { globalizacijos vyksta beprecedente ekonomiku integracija, patiriama informacinè reforma, o rinkos, } \\
\text { bendrovès, organizacijos ir valdymas tampa labiau tarptautinis. }\end{array}$ \\
\hline (Baul & $\begin{array}{l}\text { Globalizacija - kapitalo, finansu ir kitu pasirinkimo bei efektyvaus veikimo ištekliu kaupimas, o } \\
\text { kartu judejjimo ir veikimo laisves kaupimas. }\end{array}$ \\
\hline ,2007) & $\begin{array}{l}\text { Globalizacija yra dinamiškas ir atviras procesas, valstybės nyksta, o jas ardančios jègos yra } \\
\text { transnacionalinès. Žmogus nèra pajègus pakreipti ċvykių, jis tik gali stebèti, kaip ribos, institucijos } \\
\text { keičiasi ir juda nenuspejamu keliu. Tai procesas, kuris paliktas savieigai ir jo kontroliuoti iš esmès } \\
\text { valstybès negali. Globalizacija pasireiškia ir veikia visas žmogaus gyvenimo sritis: ekonomiką, } \\
\text { politiką, socialines struktūras ir netgi žmonių laiko ir erdvès suvokimą. }\end{array}$ \\
\hline (Harr & bendrai reiškia pasaulinę žmonijos integraciją, laiko ir erdvės dimensijų susitraukimą \\
\hline $\begin{array}{l}(\mathrm{Hel} \\
(200\end{array}$ & $\begin{array}{l}\text { Globalizacija traktuotina: <..> kaip visų šiuolaikinio gyvenimo aspektu (nuo kultūrinio iki } \\
\text { kriminalinio, nuo finansinio iki dvasinio) tarpusavio ryšio plètotè, gilèjimas ir greitėjimas pasauliniu } \\
\text { mastu. }\end{array}$ \\
\hline (Helc & $\begin{array}{l}\text { Globalizacija - tai procesu visuma, apimanti socialinių santykiụ ir sandorių organizavimo erdvèje } \\
\text { transformacijas, sukuriančias tarpkontinentinius ar tarpregioninius veiklos, sąveikos bei valdžios } \\
\text { itakos srautus ir tinklus. }\end{array}$ \\
\hline $\begin{array}{l}\text { (Lechn } \\
2004)\end{array}$ & $\begin{array}{l}\text { Globalizacija - pasaulinè ekonominè daugelio anksčiau tarpusavyje nepriklausomų (atskirų) } \\
\text { valstybių integracija i vieną globalią ekonomiką, per laisvą prekybą ir laisvą kapitalo judejjimą, kurią } \\
\text { itin skatina transnacionalinès korporacijos, taip pat lengva ir nekontroliuojama migracija. }\end{array}$ \\
\hline ,2005) & globalinei rinkai, nacionalinès \\
\hline $\begin{array}{l}\text { (Ohmae } \\
2000)\end{array}$ & 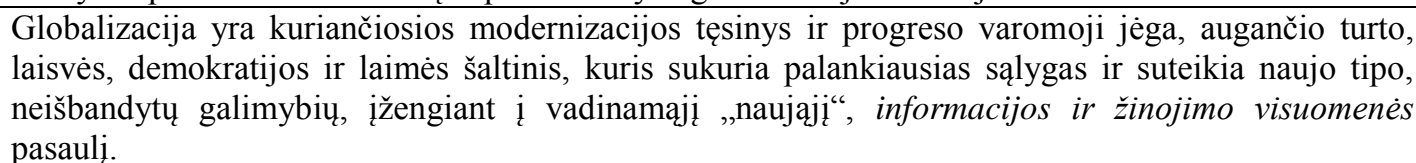 \\
\hline $\begin{array}{ll}(\mathrm{Schu} \\
1999)\end{array}$ & $\begin{array}{l}\text { obalizacija - rinku ir i̇moniu pasaulinis susiliejimas. Tokiu atveju rinkos ir i̇monès, ịskaitant ir jų } \\
\text { iklą bei juose vykstačius procesus, apibūdinami kaip globalizacijos objektai ar objektų grupè. }\end{array}$ \\
\hline $\begin{array}{l}\text { Tarptautinių } \\
\text { žodžių žodynas } \\
(2001)\end{array}$ & $\begin{array}{l}\text { Globalizacija - tai visą pasauli apimančios rinkos skverbimasis i šalių gyvenimą, sukeltas } \\
\text { stiprèjančios tarptautinès finansu rinkos, didejjančios pasaulinès prekybos, daugianacionalinių } \\
\text { bendrovių kūrimosi, telekomunikacijų naujovių. }\end{array}$ \\
\hline (Zedillo, 2008) & $\begin{array}{l}\text { Globalizacija - tai vis didèjanti nacionalinių ekonomikų, visuomenių pasaulinè integracija, } \\
\text { peržengianti nacionaliniụ valstybių sienas, ypatingai ítakojama tarptautinès prekybos, kapitalo } \\
\text { srautų, žmonių ir idèjų srautų, kultūros ir technologijos transformacijų ir tarptautinio } \\
\text { reglamentavimo. }\end{array}$ \\
\hline
\end{tabular}

Pastaba: sudaryta autorių, remiantis Amerikos gynybos instituto (2009); (Bauman, 2002; Bauman, 2007; Harris, 1995; Held ir kt., 2002; Held, 2002; Lechner, Boli, 2004; Ohmae, 2005; Ohmae, Sklair, 2000; Schumann, 1999; Zedillo, 2008) ir Tarptautinių žodžių žodyno (2001) duomenimis.

Atliktas tyrimas parodè, kad globalizacija yra itin kompleksinis fenomenas, apimantis ir įtakojantis beveik visas šiuolaikinio gyvenimo sritis, todèl praktiškai neimanoma pateikti tokị jo apibrèžimą, kuris būtu išsamus ir trumpas. Aukščiau pateiktos formuluotès neprieštarauja viena kitai, o tik papildo viena kitą bei leidžia išryškinti svarbiausius globalizacijos bruožus. Taigi, atlikus mokslinès literatūros analizę, galima konstatuoti, jog vienareikšmès globalizacijos sampratos nèra. Apibendrinant aukščiau pateiktas apibrezžtis, globalizaciją galima apibrežti kaip intensyvų ir nepertraukiamą prekių, paslaugų, kapitalo (arba pinigų), technologijų, idejjų, informacijos, kultūrų ir tautų (žmonių) judejjimą, kertantị valstybių sienas, taip pat vis 
didejjančią ekonominę atskirų valstybių integraciją, kuri yra skatinama augančios prekybos ir investicijų. Kaip išplaukia iš skirtingų autorių apibrežimų, „globalizacijos“ terminas apima labai daug skirtingų sąvokų. Globalizacijos negalima traktuoti vien kaip politinio ar ekonominio proceso, ar pasaulinio prekių, finansiniu srautų judejjimo apibrèžties. Globalizacija reiškia jungtinị, visą apimantį procesą, ị kurị įeina visos išvardintos dimensijos.

\section{Globalizacijos skatinamųjų jègų, potencialo, savybių, privalumų bei trūkumų analizė Europos pereinamosios ekonomikos šalių kontekste}

Europos pereinamosios ekonomikos šalių ekonomikos sparčiai integruojasi i globalią ekonomiką. Šis procesas yra veikiamas globalizacijos skatinamujų jègų. Mokslininkai (Jatuliavičienė, 2009; Yip, 2005; Johnson, Scholes, Whittington, 2005) apibendrina pasikeitimus nulemiančias globalizacijos skatinamąsias jègas ir jų sritis: rinką, konkurenciją, kaštus, technologijas ir vyriausybę - pagrindines aplinkybes, kuriančias potencialą ekonominei veiklai ir jos ūkio subjektams tapti globalesniems, sukuriančias palankias sąlygas globaliai strategijai formuoti ir ištekliams paskirstyti globaliu mastu (žr. 1 pav.).

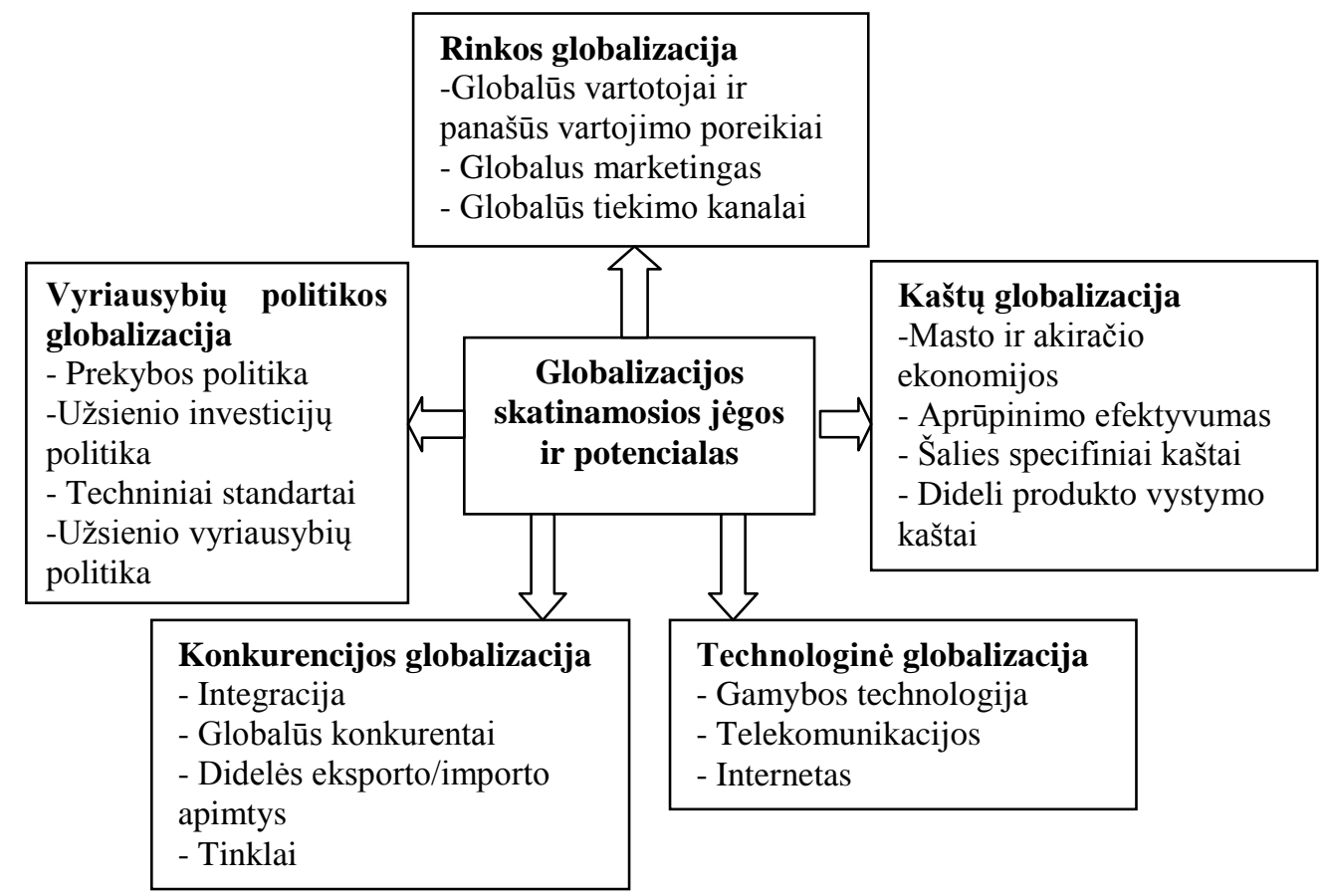

1 pav. Globalizacijos skatinamosios jègos ir potencialas*

* - originaliame tekste (angl.), ,globalization drivers and potential“.

Šaltinis: (Jatuliavičienė, 2009; Yip, 2005; Johnson, Scholes, Whittington, 2005).

Atkreiptinas dėmesys, kad ne atskiros, nors ir reikšmingos, jègos, o bendras jų derinys skatina Europos pereinamosios ekonomikos šalių ekonomikos subjektus ieškoti plètros galimybių už savo šalies rinkos ribų (globalizuotis). Anot mokslininkès Jatuliavičienès (2009), globalios ekonomikos sisteminis suvokimas ị pirmają vietą iškelia globalios rinkos vartotoją, nes besiformuojančioje globalios ekonomikos erdvèje, pasauliui tampant viena rinka, vartotojas tampa pagrindine globalizacijos skatinamaja jẻga. Todèl darytina išvada, kad Europos pereinamosios ekonomikos šaliu ekonomikos subjektai įsitraukdami i integruotas tiekimo ir gamybos sistemas tarptautiniu mastu palaipsniui tampa internacionalizuoti ir vis labiau globalizuoti.

Mokslinëje literatūroje nèra bendro sutarimo ne tik dèl globalizacijos apibrèžties, bet ir dèl reiškinio privalumų bei trūkumų. Atlikus mokslinès literatūros analizę globalizacijos tematika, galima teigti, jog globalizacijos fenomenas vertinamas itin nevienareikšmiškai. Vieni autoriai (Wolf, 2001; Bauman, 1998; Bhagwati, 2004; Giddens, 2000; Held, 2002; Dreher, 2008; Legrain, 2003) teigia, jog globalizacija yra teigiamas reiškinys, jis atveria uždaras sienas ir suteikia galimybę visuomenèms ar valstybèms pasisemti iš kitų valstybių patirties ir perimti iš jų tai, kas geriausia. Kita dalis mokslininkų (Guillen, 2000; Naim, 2009; Easterly, 2008) pabrèžia neigiamą globalizacijos įtaką. Net atskiri globalizacijos aspektai, kaip milžiniškas 
konkurencijos mastas ar spartus ekonominis augimas turi vienodai tiek kritikų, tiek šalininkų. Sugrupuoti globalizacijos aspektus i privalumus bei trūkumus - nelengvas uždavinys, nes remiantis skirtingais globalizacijos tema rašančiais autoriais, be to, skirtingais kontekstais, jie gali atsidurti tiek vienoje, tiek kitoje kategorijoje.

2 lentelè. Globalizacijos privalumai ir trūkumai Europos pereinamosios ekonomikos šalių kontekste

\begin{tabular}{|l|l|}
\hline \multicolumn{1}{|c|}{ Globalizacijos privalumai } & \multicolumn{1}{c|}{ Globalizacijos trūkumai } \\
\hline - Demokratijos idėjų sklaida; & - Atskirais atvejais - valstybių suvereniteto beprecedentis \\
- Efektyviau paskirstomi ištekliai; & sumažėjimas; \\
- Išaugę pragyvenimo standartai; & - Pajamos ne visada paskirstomos tolygiai; \\
- Išaugęs informacijos ir technologijų prieinamumas; & - Visuotinès integracijos sąlygotas tarptautinių rinkų \\
- Išaugusios konkurencijos teigiamas efektas: prekių ir & pažeidžiamumas; \\
paslaugų kainos dirbtinai nekyla, skatinamas & - Daugybė aplinkosaugos problemų; \\
išradingumas, kūrybiškumas ir inovacijos; & - Skirtingų kultūrų asimiliacija ir nykimas; \\
- Pigesnès produkcijos prieinamumas vartotojams; & - Išaugusios konkurencijos ir efektyvumo siekimo \\
- Spartesnis ekonominis augimas, kas sąlygoja naujų & neigiami aspektai; \\
darbo vietų sukūrimą; & - Multinacionalinių korporacijų (MNE) hegemonija; \\
- Sumažęjęs skurdas; & \\
- Technologiniai pasikeitimai; & \\
\hline
\end{tabular}

Pastaba: sudaryta autorių, remiantis (Kirtiklis, 2002; Ohmae, 2000; Sachs, 1998; Ritzer, 2010; Stiglitz, 2002; Wolf, 2001; Zedillo, 2008; Lechner, 2004; Held, 2002).

Nurodoma nemažai svarbių aspektų, kuriuos yra sunku priskirti globalizacijos privalumams ar trūkumams. Juos apibendrindamas, autorius Ohmae (2000) teigia, jog globalizacijos amžiuje pasikeite anksčiau aktualios, vadinamosios keturios „I“:

1) investavimas (angl. investment), kuris jau nebepriklauso nuo geografijos (deteritorizacija);

2) pramonè (angl. industry), kurios judejjimas bei kitimas mažiau priklauso nuo valstybių;

3) informacinès technologijos (angl. information technology), kurios padare i̇manomu kompanijos veikimą visame pasaulyje sunaudojant kuo mažiau resursų;

4) vartotojai (angl. individual consumers), kuriems nebe taip svarbu, kur pagamintas produktas - svarbiau, kad jis būtų kokybiškas.

Anot autoriaus šios keturios priežastys sumenkina nacionalinès valstybės kaip tarpininkès vaidmeni ir reikalingumą.

Tuo tarpu Sachs (1998), diskutuodamas apie globalizacijos teigiamas ir neigiamas puses - kelia šiuos pagrindinius klausimus iš kurių formuojasi keturios pagrindinės diskusijų apie globalizaciją kryptys:

1. Ar globalizacija sąlygos greitesnị ekonomikos augimą? Ypatingai tai pasaulio gyventojų daliai, kurie gyvena besivystančiose šalyse?

2. Kaip globalizacija paveiks/įtakos makroekonominị šalių stabilumą?

3. Ar globalizacija neskatina pajamų nelygybès?

4. Kaip visų lygių (šalies, regioninio ir tarptautinio) institucijos integruos ir suderins savo jègas ir atsakomybę naujoje globalioje plotmèje?

Mokslininkas Grižas (2006) neskirstydamas ị privalumus ir trūkumus išskiria pagrindines sąvokas, apibūdinančias globalizacijos fenomeno savybes, kurios pateikiamos 3 lentelèje.

3 lentelè. Globalizacijos fenomeno savybès

\begin{tabular}{|l|l|}
\hline \multicolumn{1}{|c|}{ Sąvoka } & \multicolumn{1}{c|}{ Aprašymas } \\
\hline $\begin{array}{l}\text { Demokratinis } \\
\text { valdymas }\end{array}$ & $\begin{array}{l}\text { Globalizacija šiandien kelia visiškai neištirtas istorines politines ir normatyvines dilemas, kurios } \\
\text { neturi analogų ankstesnėse epochose, pavyzdžiui: kaip suderinti teritoriškai išsišaknijusi } \\
\text { demokratini valdymą su transnacionaliniu ir globaliniu socialinio-ekonominio gyvenimo } \\
\text { organizavimu. }\end{array}$ \\
\hline Erdvė ir laikas & $\begin{array}{l}\text { Istoriškai beprecedentinis globalinių srautų sąveikų ir tinklų intensyvumas, pasireiškiantis visose } \\
\text { socialinėse sferose. }\end{array}$ \\
\hline Konjunktūra & $\begin{array}{l}\text { Unikalus globalinès įtakos visuose socialinio gyvenimo aspektuose susiliejimas - nuo politikos } \\
\text { iki ekologijos. }\end{array}$ \\
\hline Konkurencija & Didèjantis globalizacijos suvokimas skatina varžytis visose sferose nuo kultūrinės iki karinės. \\
\hline Lankstumas & Besiplečiantis pasaulinis elitas ir visuotinis pasaulinio tarpusavio ryšio supratimas. \\
\hline Organizacija & Institucionalizacija ir pasaulinio masto socialinių, politinių ir ekonominių jègų stiprèjantys ryšiai. \\
\hline
\end{tabular}




\begin{tabular}{|c|c|}
\hline Regionalizacija & $\begin{array}{l}\text { Šiuolaikiniai globalizacijos ir regionalizacijos procesai tapo viena kitą stiprinančiomis } \\
\text { tendencijomis. }\end{array}$ \\
\hline $\begin{array}{l}\text { Skirtingas } \\
\text { modalumas }\end{array}$ & $\begin{array}{l}\text { Didèjanti visų migracijos formų reikšmė kultūrinèje ir ekologinèje globalizacijos formose šalia } \\
\text { karinės, ekonominès ir politinès globalizacijos. }\end{array}$ \\
\hline Teritoriškumas & $\begin{array}{l}\text { Teritorija ir teritoriškumas lieka labai politizuoti, nors šiandien grèsmės teritoriškai integruotos i } \\
\text { nacionalines valstybes jau nebėra tiktai išorinės ar karinès. Karinè jëga jau nebėra vienintelis } \\
\text { racionalus ar efektyvus instrumentas sienų perkèlimo klausimams spręsti. }\end{array}$ \\
\hline Vakarietinimas & $\begin{array}{l}\text { Didžioji globalizacijos istorijos dalis buvo pasaulio vakarietinimas ir Vakarų valstybių kova dèl } \\
\text { pasaulinès ịtakos. Nors visos dar labai asimetriškos, šiuolaikinès globalizacijos formos tapo vis } \\
\text { mažiau „eurocentrinės“ ir ,,atlantocentrinès“. }\end{array}$ \\
\hline Valstybės formos & $\begin{array}{l}\text { Ivairios istorinès globalizacijos formos buvo susijusios su labai skirtingomis istorinemis } \\
\text { valstybių formomis. }\end{array}$ \\
\hline
\end{tabular}

Šaltinis: (Grižas, 2006).

Europos pereinamosios ekonomikos šalių ekonomikos subjektų verslo aplinkoje galima aptikti beveik visas aukščiau išvardintas globalizacijos fenomeno savybes. Kuo labiau globalizuota šalis, kuo sèkmingesnis jos vidinių reformų vykdymas ir implementavimas, tuo labiau pasireiškia šios globalizacijos fenomeno savybès.

\section{Esminių globalizacijos poveikio veiksnių Europos pereinamosios ekonomikos šalių verslo aplinkai analizè}

Atlikta literatūros analizè atskleidè, jog daugelis globalizacijos problematiką nagrinèjančių autorių nesutaria ne tik dèl globalizacijos sampratos ir tipologijos, teigiamybių bei neigiamybių, bet ir dèl globalizacijos poveikio veiksnių. Literatūroje pastebima ir jų įvardijimo įvairové: vieni autoriai juos vadina akseleratoriais (angl. accelerators), kiti - bruožais (angl. attributes), treti - veiksniais (angl. factors, elements, ingredients). İvairių autorių nurodomi globalizacijos veiksniai pateikiami 4 lentelëje.

4 lentelè. Globalizacijos poveikio veiksniai

\begin{tabular}{|c|c|}
\hline Autorius (metai) & Globalizacijos veiksniai \\
\hline (Stounhouse, 2000) & $\begin{array}{l}\text { 1. ekonominiai veiksniai - didèjančios pajamos, pasaulinė prekyba, pasaulinės finansų rinkos, } \\
\text { rinkos jègos, pasaulinè konkurencija; } \\
\text { 2. politiniai veiksniai - sumažinti prekybos barjerai, intelektinès nuosavybès teisès, } \\
\text { privatizacija, regioninių prekybos blokų plètojimasis, nauji techniniai standartai; } \\
\text { 3. socialiniai veiksniai - vartotojų teisių gynimas, vartotojų skonių supanašèjimas, mokymas } \\
\text { ir žinios; } \\
\text { 4. technologiniai veiksniai - industrializacija, transporto evoliucija, informacijos } \\
\text { pereinamumas, komunikacijos proceso vystimasis. }\end{array}$ \\
\hline (Pugačiauskas, 2000) & $\begin{array}{l}\text { 1. tarptautinès konkurencijos kokybinio pobūdžio kitimas ir apimties augimas - naujausios } \\
\text { technologijos leidžia konkuruoti tose srityse, kur anksčiau valstybių ar regionų ribose buvo } \\
\text { galima išlaikyti monopolijas; } \\
\text { 2. inovacijų kaupimasis, keičiantis prekių gamybą paslaugų kūrimu, o tradicinėms ịmonems } \\
\text { suteikiantis lankstumo (kitaip negu pirmajai sąlygai, antrajai, kad ji padarytų realų poveikị } \\
\text { valstybès ekonomikai, būtinas tam tikras valstybės (de)reguliacinis pagrindas); } \\
\text { 3. strateginiai aljansai ir transnacionalizacija, leidžianti apjungti galimybę plèsti gamybą ị } \\
\text { ivairius geografinius regionus su lankstumu bei specifinių žinių pritaikymu. Visa tai } \\
\text { sukuria naują tarptautini darbo pasidalijimą. }\end{array}$ \\
\hline $\mathrm{ch}, 2007)$ & $\begin{array}{l}\text { 1. multinacionalinių korporacijų (MNE) bei finansinio kapitalo hegemonija; } \\
\text { 2. ekonominių ir politinių funkcijų perskirstymas tarp nacionalinių valstybių, } \\
\text { transnacionalinių korporacijų ir tarptautinių organizacijų; } \\
\text { 3. viršvalstybinio reguliavimo dominavimas bei nacionalinio reguliavimo vaidmens } \\
\text { mažejimas. } \\
\text { Autorius akcentuoja multinacionalinių korporacijų ir pasaulinių finansų rinkų vaidmenị } \\
\text { nacionalinių ūkių vystimęsi, bei teigia, jog globalizacijos amžiuje valstybės nebepajègios } \\
\text { reguliuoti ekonominių, socialinių procesų, kurie tampa vis labiau savarankiški ir išeina iš } \\
\text { nacionalinių ribų. }\end{array}$ \\
\hline
\end{tabular}

Pastaba: sudaryta autorių, remiantis (Stounhouse, 2000; Pugačiauskas, 2000; Makarevich, 2007). 
Apibendrinant ịvairiu globalizacijos problematiką nagrinėjančių mokslininkų (Wolf, 2001; Bauman, 1998; Bhagwati, 2004; Giddens, 2002; Held, 2002; Dreher, 2008; Legrain, 2003; Guillen, 2000; Naim, 2009; Easterly, 2008; Bauman, 2002; Bauman, 2007; Harris, 1995; Held ir kt., 2002; Held, 2002; Lechner, Boli, 2004; Ohmae, 2005; Ohmae, Sklair, 2000; Schumann, 1999; Zedillo, 2008) darbus, galima išskirti šiuos dažniausiai moksliniuose darbuose išskiriamus globalizacijos poveikio veiksnius:

1) Visuotinis mobilumo ir prieinamumo augimas. Gèrybès, paslaugos, ịvairūs ištekliai (materialiniai, finansiniai ir kt.), naudingos iškasenos, informacija, žinios, technologijos, idèjos, kultūra, kurie seniau buvo prieinami tik atskiroms geografinėms grupėms, interneto ir kitụ technikos naujovių dèka tampa mobilūs ir jais gali naudotis neribotas (nei kiekybe, nei geografiškai) vartotojų ratas. Be to, nepaprastai išaugo ir pačių vartotojų mobilumas: anksčiau laikyti neįveikiami atstumai (pavyzdžiui, atstumai tarp kontinentų), dabar ịveikiami per kelias valandas. Be to, anot (Cekanavicius \& Kasnauskiene, 2009), technologinè pažanga sąlygojo ir masto efektą: kelionès, transportavimas ženkliai atpigo ir tapo prieinamas daug didesniam vartotojų ratui, taip dar labiau paspartindamas mainus.

2) Mobilumo (mainų) kliūčių mažèjimas. Kaip viena svarbiausių globalizacijos ir technologinès pažangos išdava, yra laikoma šių kliūčiu nykimas:

- fiziniu kliūčių, tokių kaip valstybinès sienos. İvairių transporto priemonių tobulëjimas faktiškai panaikino atstumus ir fizines mobilumo kliūtis iš esmès.

- ekonominiu kliūčių, tokių kaip ịvairūs valstybiniai muitai, ekonominiai apribojimai, ịvairūs verslo suvaržymai. Nors, anot Stiglitz (2002) visiškas verslo veiklos sąlygų liberalizavimas sulaukia daugybès kritikos iš antiglobalistų pusès, tačiau, kaip teigia (Snieška \& Drakšaitè, 2007; Snieška, 2008) ekonominių kliūčių mažèjimas yra nesustabdomas procesas.

- finansiniu kliūčių nykimas, kuris, anot (Bernatonytès \& Normantienès, 2007), yra daugiausiai sąlygotas visuotinio finansų pasaulio virtualizavimo, bei vis liberalesnio valstybių požiūrio ị apmokestinimą.

- teisiniu kliūčių. Daugelis vakarų valstybių jau yra unifikavę (receptavę) daugybę bendros praktikos teisès aktų. Šis procesas ir toliau sklandžiai vyksta, o procesą itin palengvina tokios tarptautinès institucijos ar dariniai, kaip Jungtinès Tautos, Europos Sajunga, NATO ir kt. Daugelis anksčiau buvusių atskirų sistemų yra pamažu sinchronizuojamos, idant paskatinti ir padidinti jų pasiekiamumą, vartojamumą ir kokybès kontrolę.

- kalbiniu kliūčių. Nors pasaulyje yra vis labiau mokomasi užsienio kalbų, ịvairių techniniu priemonių, specialių programų ir interneto pagalba vis labiau tampa įmanoma komunikuoti net ir tomis kalbomis, kuriomis nekalbama. Tai šimteriopai palengvina komunikaciją tarp atokiausiu pasaulio kampelių. Bene labiausiai kalbinių kliūčių nykimui pasitarnauja anglų kalba. Nors ir pagal kalbančiųjų skaičių ji tẻra trečioji kalba pasaulyje (žr. 5 lentelę), daug kas anglų kalbą vadina globalia kalba. Anglų kalba tapo oficialia aviacijos ir daugelio tarptautinių sutarčių kalba, taip išstumdama prancūzų, kuri iki XXa. vidurio laikyta oficialia teisine tarpvalstybinių sutarčiu ir susitarimų kalba Europoje. Didelèje Afrikos dalyje (buvusiose kolonijose), taip pat Kanados Kvebeko ir Akadijos provincijose prancūzų kalba iki šiol išlaikè savo hegemoniją.

5 lentelè. 2011 metais populiariausios pasaulio kalbos

\begin{tabular}{|l|l|}
\hline 1. Kiniečių (mandarinų) & 882 milijonai kalbančiujjų \\
\hline 2. Ispanų & 325 milijonai kalbančiųų \\
\hline 3. Anglų & $312-380$ milijonai kalbančiujų \\
\hline 4. Arabų & $206-422$ milijonai kalbančiųjų \\
\hline 5. Hindi & 181 milijonai kalbančiuujų \\
\hline 6. Portugalų & 178 milijonai kalbančiujų \\
\hline 7. Bengalų & 173 milijonai kalbančiujų \\
\hline 8. Rusų & 146 milijonai kalbančiujų \\
\hline 9. Japonų & 128 milijonai kalbančiujų \\
\hline 10. Vokiečių & 96 milijonai kalbančiųų \\
\hline
\end{tabular}

Šaltinis: sudaryta autoriu pagal: www.geography.about.com (2012) duomenis.

- kultūriniu kliūčių. Pasauliui vis labiau integruojantis, ekonomikoms vis labiau patiriant susiliejimo efektą, nelieka nepaliesta ir kultūra. Nors daugelis antiglobalistų priekaištu globalizacijos procesui yra ne tik ekonominès, bet ir kultūrinès prigimties, kultūra vis dèl to yra 
stipriai veikiama globalizacijos. Nors savo kultūrinio identiteto išsaugojimas, ypač mažose valstybėse, kaip Baltijos šalys, yra labai svarbus kiekvienam individui, svetimos kultūros ar globalios „mišrios“ kultūros produktai yra vis palankiau priimami ir randa savo vietą bendrame nacionalinès kultūros kontekste. Be to, intensyvejjant ekonominiam bendradarbiavimui, vis labiau perimama ir svetima kultūrinė patirtis, kuri tik labiau skatina toleranciją ir kultūrinių kliūčių, buvusių stereotipų bei prietarų nykimą.

3) Geografinès vietos reikšmingumo nykimas ir IT svarba. Informacinès technologijos, visuotinè skaitmenizacija, interneto sklaida suteikia galimybes susiekti, prieiti prie išteklių nepriklausomai nuo vartotojo lokacijos. Daugeli prekių, paslaugų vartotojas gali įsigyti net nepakilęs iš savo darbo vietos. Virtualus pasaulis sudaro galimybes apsirūpinti materialiais bei kitokiais pragyvenimo šaltiniais, medžiagomis ir patenkinti daugelị poreikių įdedant kuo mažiau pastangų.

4) Laiko reikšmės didėjimas. Nors technologinè pažanga, virtualizacija ir sutaupo daugybę žmonių laiko, paradoksalu, tačiau šiuolaikiniam žmogui jo vis labiau trūksta. Nuolatinis skubejjimas, tik paskutiniai ar „mirtini“ terminai (angl. deadlines), tampa norma. Darbuotojai imti vertinti ne tik pagal profesionalumą, bet ir operatyvumą, gebejjimą greitai, žaibiškai reaguoti ị pokyčius. Anot Held (2002), geriausias darbuotojas yra tas, kuris per šio ryto susirinkimą gautą užduotį yra atlikęs jau vakar.

5) Visuotinumas ir proceso greičio augimas. Globalizacijos procesas neturi išimčių. Globalizacija skirtingais laipsniais paveikia absoliučiai visas gyvenimo sritis, subjektus, objektus ar kitus reiškinius. Daugelis mokslinių studijų, vertinančių globalizacijos poveikị, vieningai konstatuoja, jog anksčiau daugmaž tolygiai plètojęsis šis procesas ịgauna milžinišką pagreitį.

Autorius Kolodko (2000) kritikuoja dabar dažnai sutinkamą globalizacijos supaprastintą apibūdinimą, kaip „naujas mąstymas“, „kapitalizmo stadija“ ar „vèlyvoji modernybe“. Mokslininkas išskiria penkias skirtingas koncepcijas, iš kuriu jo nuomone, susideda šiandieninis globalizacijos turinys :

1) Pirmoji - internacionalizacija, kuri plačiaja prasme reiškia nevaržomus ryšius tarp skirtingu valstybių, tarptautinius mainus ar laisvą prekybą.

2) Dar vienas terminas, kuri įtraukia globalizacija - liberalizacija, kurios esmè - vyriausybiu panaikinti apribojimai judèti tarp valstybių, taip kuriama atvira erdvè, pasaulinè ekonomika.

3) Universalizacija - universalus, globalus kultūros ar tam tikrų reiškinių suvokimas, „pasaulinis“ matymas.

4) Modernizacija arba vesternizacija, kuri daugelio autorių dar vadinama kaip „amerikonizacija”. Modernizacija ar vesternizacija taip pat reiškia lokalių kultūrų nunykimą. Geriausias to pavyzdys, visuotinis televizijos kanalu (CNN, BBC ir kt.), greito maisto restoranų McDonald's ar Holivudo filmų įsigalëjimas, kurie išstumia vietinę produkciją ir tampa jos pakaitalais.

5) Deteritorizacija, kuri, anot Kilijonienès et al., 2010 reiškia geografinių sienų, ribų nunykimą, socialinès ir geografinès erdvès nesutapimą. Mokslininkai (Sachs, 1998; Ohmae, 2000; Stiglitz, 2002; Wolf, 2001; Lechner, 2004) apibūdinami deteritorizaciją naudoja globalaus kaimo (angl. global vilage) metafora.

Šiandieninę pasaulio ekonomiką galima laikyti ir globalizacijos atspindžiu, ir laidininku. Pugačiauskas (2000) teigia, jog šis procesas daro reikšmingos įtakos tarptautinėms kapitalo rinkoms, prekių rinkoms, makroekonominei (biudžeto) politikai, pramonès santykiams ir darbo rinkos reglamentavimui. Autorius skiria tris globalizacijos lygius:

1. Transakcijas per sieną (angl. cross-border transactions);

2. Transakcijas bendroje rinkoje (angl. open-border transactions);

3. Transakcijas be sienų (angl. transborder transactions) - dažniausiai naudojamą ,interneto amžiaus" ekonomikos pavyzdị.

Mokslinèje literatūroje kai kur aptinkamas įmonių skirstymas pagal pasiektą globalizacijos lygmenị. Paprastai yra nustatomi trys globalizacijos lygmenys. Pirmas lygmuo - tarptautine ịmoné, turinti centrini ofisą vienoje valstybejje ir filialus - kitose valstybėse. Pirmojo lygmens įmonè dažniausiai internacionalizuodamasi taiko savo valstybès tendencijas, o ne deda pastangas integruotis ì globalią ekonomiką. Antrasis lygmuo - tai daugianacionalinè įmonè. Šiame lygmenyje verslas susideda iš keleto nepriklausomų junginių, kurie veikia skirtingose šalyse, neturèdami daug bendradarbiavimo sąsajų. Trečiasis lygmuo - globali kompanija. Šio lygmens įmonè vertina pasaulị kaip vieną rinką, kuria ir ịgyvendina bendrą įmonès strategiją visame pasaulyje ir išnaudoja kiekvienos šalies patirtí, grịsdama savo globalią sėkmę. Šiame straipsnyje yra daroma prielaida, jog dauguma Europos pereinamosios ekonomikos šalių ekonomikos 
subjektų yra „pirmojo“ lygio įmonès, (turinčios būstinę vienoje šalyje, o filialus kitose) arba tik lokaliai dirbančios įmonès.

\section{Europos pereinamosios ekonomikos šalys ir jų verslo aplinkos ypatumų analizė}

Kaip apibrěžia daugelis autorių, pereinamosios ekonomikos šalimi (angl. transition economy arba transitional economy) yra laikoma šalis, pereinanti iš centrinio planavimo sistemos i laisvą rinkos ekonomiką. Kaip teigia (Feige, 1991; Lakstutienè et al., 2009), pereinamosios ekonomikos šalys turi pereiti ekonominę liberalizaciją, kur kainas nustato pati rinka, o ne centrinio planavimo sistema. Kaip esminiai pereinamosios ekonomikos šalies uždaviniai yra įvardijami: prekybos barjerų panaikinimas, valstybinių ìmonių bei išteklių privatizacijos vykdymas, finansinio sektoriaus sukūrimas, makroekonominio stabilumo bei laisvo privačiu lěšų judėjimo užtikrinimas. Šis procesas yra/buvo vykdomas Kinijoje (didžiausia pereinamosios ekonomikos šalis pasaulyje), buvusios Sovietų Sajungos narèse, tarp jų ir Baltijos valstybėse, taip pat trečiojo pasaulio ${ }^{2}$ šalyse. Pereinamasis procesas dažniausiai susideda iš naujų valstybinių bei privačių ekonomikos subjektų kūrimo, ar esamų restruktūrizavimo, valstybės vaidmens visuomenès gyvenime ir versle kitimo, privačios verslo iniciatyvos skatinimo, laisvų rinkų ir nepriklausomų finansinių institucijų kūrimo.

Mokslinėje literatūroje, kaip esminis pereinamosios ekonomikos bruožas, yra ịvardijamas privačios nuosavybès teisių buvimas. Kaip apibrěžia Bitzenis (2007) - tai yra ir rinkos ekonomikos pagrindas. Tarptautinio valiutos fondo (2010) ataskaitoje apibrezžiami tokie pereinamosios ekonomikos bruožai:

1. Liberalizacija - leidimas beveik visoms kainoms būti apspręstoms laisvoje rinkoje, taip pat prekybos barjerų sumažinimas, kurie trukdè sąsajoms su analogiškų prekių/paslaugų kainų struktūromis laisvose rinkose.

2. Makroekonominè stabilizacija - infliacijos suvaldymas ir, laikui bėgant, mažinimas po beveik visų pereinamujų ekonomiku patirto infliacijos šuolio, kuris sekè po paklausos ir pasiūlos liberalizavimo. Anot Aristovnik (2006), šis procesas reikalauja ypatingos monetarinès ir fiskalinès disciplinos, t. y. valstybė turi ,protingai“ kontroliuoti valstybės išlaidas, pinigų kiekio augimą, bei kreditavimą ir taip siekti tvaraus (angl. sustainable) mokèjimų balanso.

3. Restruktūrizavimas ir privatizacija - veikiančio ir efektyvaus finansų sektoriaus sukūrimas ir valstybinių imoniu perdavimas į privačias rankas, jas paverčiant moderniais ir šiuolaikiniais paslaugų teikèjais/gamintojais, kurie būtu pajègūs konkuruoti tarptautinèje rinkoje.

4. Teisinès ir institucinès reformos - valstybès vaidmens kitimas, teisinių valstybių kūrimas, kuriose būtų saugomos privačios nuosavybès teisès, autorinès teisès, bei būtų saugoma ir skatinama konkurencija.

Anot mokslininkų Havrylyshyn ir Wolf $(1999,2010)$ pereinamasis procesas plačiaja prasme susideda

iš:

1. Efektyvaus ekonomikos subjektų valdymo ir ekonominio efektyvumo, dažniausiai paskatinto privatizacijos, pasiekimo;

2. Ekonominès veiklos, kainų, rinkos operacijų liberalizavimo, išteklius paskirstant efektyviausiu būdu;

3. Griežtų biudžeto rẻmų, kurie skatintų ekonominị efektyvumą, nustatymo;

4. Institucinès ir teisinès sistemos, kuri užtikrintų nuosavybès teises, įstatymų valdžią ir skaidrų patekimą ị rinką, sukūrimo;

5. Netiesioginių, į rinką orientuotų instrumentų makroekonominiam stabilizavimui sukūrimo.

Europos rekonstrukcijos ir plètros banko (ERPB) tyrejjai apibrěžè rodiklių rinkinį, kuriais yra išmatuojamas pereinamojo laikotarpio progresas. Ši klasifikavimo sistema pirmą kartą buvo sukurta 1994 metais ERPB pereinamojo laikotarpio ataskaitoje ("EBRD Transition Report 1994") kaip instrumentas

\footnotetext{
2 Dabar plačiai naudojamą terminą “trečiojo pasaulio šalys" pirmą kartą savo straipsnyje žurnale L'Observater (1952 08 14 numeryje) pavartojo žymus prancūzų demografas, antropologas ir istorikas Alfredas Sauvy. Trečiojo pasaulio šalimis autorius ịvardijo šalis, kurios nepriklausè nei komunistų sovietiniam blokui, nei kapitalistiniam NATO blokui šaltojo karo laikotarpiu. Daugelis trečiojo pasaulio šalių yra buvusios kolonijos ir žlugus imperializmui susidūrè su daugeliu ekonominių bei politinių iššukių. Dèl šių priežasčių, daugelis šių šalių ekonomine prasme intensyviai vystesi XX a. laikotarpiu, ir daugelis jų tebesivysto iki šiol. Šiuo metu šis terminas reiškia, jog šalis nèra "pasiekusi" OECD šalių ekonominio išsivystymo lygio ir "vystosi” iki šiol.
} 
išmatuoti pereinamojo laikotarpio progresą, vèliau ši klasifikavimo sistema buvo patobulinta vėlesnèse ERPB ataskaitose. Taigi, pagrindiniai ERPB pereinamojo laikotarpio rodikliai yra sekantys:

1) bankininkystės reforma ir palūkanų normos liberalizavimas;

2) didelio masto privatizavimas;

3) infrastruktūros reformos;

4) kainų liberalizavimas;

5) konkurencijos politika;

6) nedidelio masto privatizavimas;

7) prekybos ir užsienio valiutų sistema;

8) valdymo ir ekonomikos subjektų restruktūrizavimas;

9) vertybinių popierių rinkos ir nebankinès finansinès įstaigos.

Mokslinèje literatūroje terminas "pereinamosios ekonomikos šalys" dažniausiai yra siejamas su Centrinès ir Rytų Europos šalimis bei buvusiomis Sovietų Sajungos narèmis, šis terminas gali turèti ir platesni kontekstą. Kai kurios socialistinio tipo, buvusios planinès ekonomikos, tokios kaip Kinija, yra taip pat priskiriamos prie pereinamosios ekonomikos šalių, nors jos ekonominis pajègumas, potencialas viršija visas pereinamosios ekonomikos šalis kartu sudejjus. Kai kur literatūroje pereinamosios ekonomikos šalimis yra apibrěžiamos visos šalys, kurios mėgina iš ankstesnių ekonominių sistemų (pvz., pokolonijinè situacija, buvusios griežtai reguliuojamos azijietiško tipo ekonomikos, podiktatūrinès valstybės, ar net labai silpnai ekonomiškai išsivysčiusios Afrikos šalys) pereiti prie rinkos ekonomikos. Šiuo metu pagal TVF (2010) ir ERPB (2010) klasifikaciją šios Europos valstybès yra laikomos pereinamosios ekonomikos šalimis: Albanija, Baltarusija, Bulgarija, Kroatija, Čekijos Respublika, Estija, Vengrija, Latvija, Lietuva, Makedonija, Moldova, Lenkija, Juodkalnija, Rumunija, Rusija, Slovakija, Slovenija, Ukraina ir Serbija.

Kiekvienos pereinamosios ekonomikos šalies perèjimo procesai ir jų priežastys yra skirtingi. Kai kurios šalys (pvz., Baltijos šalys) jau keletą dešimtmečių vykdo rinkos reformas, kai kurios dar tik šio proceso naujokès (pvz. Makedonijos Respublika, Serbija, Juodkalnija).

Mokslinèse studijose ${ }^{3}$, ERPB, TVF kasmetiniuose pranešimuose ${ }^{4}$, ịvairiose ataskaitose, tarptautinių mokslinių konferencijų sekcijose ${ }^{5}$ Čekija, Estija, Vengrija, Latvija, Lietuva, Lenkija, Slovakija ir Slovėija iki šiol priskiriamos ir nagrinèjamos kaip pereinamosios ekonomikos šalys. Nors tarptautiné enciklopedija "Wikipedia" nurodo, jog šios, ị Europos Sajungą 2004 m. ịstojusios šalys, jau ịvykdè perẻjimo procesą.

Anot ERPB, 2010; Bitzenis, 2005, vienos iš esminių verslo aplinkos problemų Europos pereinamosios ekonomikos šalyse - šešèlinė ekonomika ir aukštas korupcijos lygis. Šios problemos aktualios ir Vakaru šalyse, tačiau jų raiška tose valstybėse ne tokia ženkli. Anot Startienès ir Trimonio (2009), neoficialiai apskaitytos ekonomikos mastas JAV siekè nuo 0 iki $10 \%$, Jungtinèje Karalysteje, Naujojoje Zelandijoje, Norvegijoje - 10 - $20 \%$, tuo tarpu Slovénijoje ir Vengrijoje sudare 20 - $30 \%$, Lietuvoje, Latvijoje, Estijoje $30-40 \%$ BVP. Remiantis „Transparency International“ duomenimis pagal korupcijos indeksą 2010 m. išsivysčiusios šalys pateko tarp 1 ir 22 vietos (pavyzdžiui, Naujoji Zelandija užèmè $1(9,3)$ vietą; Norvegija $10(8,6)$ ir t. t. vietas iš 178 pasaulio valstybių), o nagrinèjamos Europos pereinamosios ekonomikos šalys pagal korupcijos indeksą varijavo nuo 26 iki 62 vietos (Lietuva užèmè 46 vietą (5); Latvija - 59 (4,3); Estija - $26(6,5)$ ). Kipro mokslininkas, Nobelio premijos laureatas Pissarides (1999) kaip dažną Europos pereinamosios ekonomikos šalių verslo problemą ịvardina - bankų patirties stoką kredituojant privatụ sektorių, organizacinių gebėjimų trūkumą verslo finansavimo atvejais. Anot mokslininko, valstybiniai bankai proteguoja valstybines ịmones bei, iš dalies, dideles privatizuotas įmones teikdami lengvatines paskolas, tačiau retai skolina privačiam sektoriui, ypač pereinamojo proceso pradžioje (Filatotchev ir Mickiewicz, 2006).

Atlikta analizė atskleidè, jog dauguma Europos pereinamosios ekonomikos šalių perèjimo procese yra padariusios pažangą tinkamos verslo aplinkos kūrime pereinamuoju laikotarpiu, tačiau yra sričių, kurios dar atsilieka ir reikia dèti nemažai pastangų, kad pasiekti išsivysčiusių valstybių lygị:

1. Didesni šešèlinès ekonomikos mastai nei išsivysčiusiose šalyse, sudarantys neįveikiamą konkurenciją legaliam verslui.

\footnotetext{
${ }^{3}$ Myant, Drahokoupil (2011) Transition Economies: Political Economy in Russia, Eastern Europe and Eastern Asia.

${ }_{5}^{4}$ EBRD transition report 2010: Recovery and Reform.

${ }^{5}$ Konferencijos „Verslininkyste kylančiose ir pereinamosios ekonomikos šalyse“, JAV, Vašingtonas, 2009 m. medžiaga, konferencijos „Ekonominio išsivystymo ir verslininkystès tyrimai pereinamosios ekonomikos šalyse“, Bosnija ir Hercogovina, Banja Luka, 2011 m., medžiaga.
} 
2. Didesnis vyriausybès kišimosi ị verslą lygis nei išsivysčiusiose šalyse. Europos pereinamosios ekonomikos šalių verslo laisvès indeksas (angl. business freedom index) yra 0,8 karto mažesnis nei Vakarų valstybėse.

3. Didesni visų lygių korupcijos mastai palyginus su išsivysčiusiomis Vakarų šalimis.

4. Vis dar gajus neigiamo požiūrio ị verslą ir verslininkus stereotipas, atėjęs iš socializmo laikų.

5. Žemas viešojo administravimo efektyvumo lygis.

6. Žemesnis vartotojų perkamosios galios lygis.

7. Nepakalnama patirtis ir pastangos formuojant verslui palankias mokesčių sistemas, kuriomis pasižymi išsivysčiusios šalys, todèl Europos pereinamosios ekonomikos šalims būdingi dažni mokesčių ir įstatyminès bazès pakeitimai.

Išsprendus aukščiau minimas problemas, Europos pereinamosios ekonomikos šalys igytų daugiau galimybių efektyviai išnaudoti globalizacijos proceso teikiamas ekonomines ir kt. galimybes, bei išvengtu (ar galètų suvaldyti) atnešamas grèsmes.

\section{Išvados}

Išanalizavus labiausiai mokslinėje literatūroje autorių cituojamas globalizacijos sampratas, darytina išvada, jog iki šiol vienareikšmès globalizacijos sampratos nèra. Atliktas tyrimas parodè, kad globalizacija yra itin kompleksinis fenomenas, todèl praktiškai neįmanoma pateikti išsamų ir trumpą jo apibrèžimą. Apibendrinant ịvairių autorių formuluotes, globalizaciją galima apibrèžti kaip intensyvų ir nepertraukiamą prekių, paslaugų, kapitalo (arba pinigų), technologijų, idèjų, informacijos, kultūrų ir tautų (žmonių) judèjimą, kertantị valstybių sienas, taip pat vis didejančią ekonominę atskirų valstybių integraciją, kuri yra skatinama augančios prekybos ir investicijų. Globalizacija yra jungtinis, visaapimantis nesustabdomas procesas, ị kuri įeina beveik visos šiuolaikinio gyvenimo dimensijos.

Atlikus globalizacijos skatinamujų jègų, potencialo, savybių, proceso privalumų bei trūkumų Europos pereinamosios ekonomikos šaliu kontekste analizę, galima konstatuoti, jog, kaip ir dèl globalizacijos apibrèžties, vieningos, objektyvios nuomonès pateikti yra praktiškai neįmanoma. Daugybė globalizacijos aspektų, tokių kaip: valstybių suvereniteto sumažèjimas, skirtingų kultūrų asimiliacija, išaugusi konkurencija ir intensyvus efektyvumo siekimas, išaugęs informacijos ir technologijų prieinamumas, įvairūs technologiniai pasikeitimai ir kt. turi tiek neigiamų, tiek teigiamų bruožų. Daugelis tyrejų apskritai negrupuoja globalizacijos aspektų i teigiamus ir neigiamus, o tiesiog apibendrina juos formuluodami klausimus ir diskusijų kryptis.

Atlikta mokslinès literatūros analizè atskleidè, jog daugelis globalizacijos problematiką nagrinèjančiu autorių nesutaria ne tik dèl globalizacijos sampratos ir tipologijos, teigiamybių bei neigiamybių, bet ir dèl esminių globalizacijos poveikio veiksnių. Dažniausiai autoriai veiksnius grupuoja ị politinius, ekonominius, socialinius ir teisinius. Daugelis mokslininkų, kaip labiausiai Europos pereinamosios ekonomikos šalių ekonomikos subjektus įtakojančių veiksnių įvardija viršvalstybinį reguliavimą, multinacionaliniu (MNE) korporacijų, milžiniškų finansinių srautų dominavimą, ekonominių ir politinių funkcijų perskirstymą tarp nacionalinių valstybių bei nacionalinio reguliavimo vaidmens laipsninį nykimą.

Išnagrinëjus Europos pereinamosios ekonomikos šalių verslo aplinkos ypatumus, galima teigti, jog kiekvienos Europos pereinamosios ekonomikos šalies perẻjimo procesai ir jų priežastys yra skirtingi. Kai kurios šalys (pvz., Baltijos šalys) jau keletą dešimtmečiu sėkmingai vykdo rinkos reformas, kai kurios yra dar tik šio proceso naujokès (pvz., Makedonijos Respublika, Serbija, Juodkalnija). Reikia pažymèti, jog remiantis skirtingais šaltiniais Čekija, Estija, Vengrija, Latvija, Lietuva, Lenkija, Slovakija ir Slovėnija iki šiol priskiriamos ir nagrinejjamos kaip pereinamosios ekonomikos šalys, nors kai kur literatūroje pažymima, jog aukščiau minėtos šalys perejimo procesą jau ịvykdè. Kaip esminès Europos pereinamosios ekonomikos šalių ekonomikos subjektų verslo aplinkos problemos, įvardijamos daugelio autorių, yra korupcija ir šešèlinė ekonomika, mažesnè vartotojų perkamoji galia, vis dar didelio masto valstybès kišimasis į verslą, vis dar gajus neigiamo požiūrio ị verslą stereotipas ir kt.

\section{References}

1. About.com. Geography. (2012). The 10 Most Popular Spoken Languages in the World. Retrieved February 02, 2012, from http://geography.about.com/od/culturalgeography/a/10languages.htm.

2. Altman, R.C. (2009). Globalization in Retreat. Journal of Foreign Affairs, 88, 3, 45-51. 
3. Aristovnik, A. (2006). The Determinants \& Excessiveness of Current Account Deficits in Eastern Europe and the Former Soviet Union. William Davidson Institute, University of Michigan. Retrieved February 04, 2012, from http://wdi.umich.edu/files/publications/workingpapers/wp827.pdf.

4. Bauman, Z. (1998). Globalization: Human Conseque nces. Cambridge: Human Press.

5. Bernatonytė, D., Normantienè, A. Estimation of Importance of Intraindustry Trade. //Engineering Economics, 2007, No 3 (53);

6. Bhagwati, J. (2004). In Defense of Globalization. New York: Oxford University Press.

7. Bitzenis, A., \& Marangos, J. (2007). Globalization and the Integration Assisted Transition in Central and Eastern European Economies. Journal of Economic Issues, 41, 2, 427-434.

8. Cekanavicius, L., \& Kasnauskiene, G. (2009). Too High or Just Right? Cost-Benefit Approach to Emigration Question. Inzinerine Ekonomika-Engineering Economics(1), 28-36.

9. Dicken, P. (2003). Global Shift: Reshaping the Global Economic Map in the 21st Century. London: SAGE Publications.

10. Dreher, A. (2006). Does Globalization Affect Growth? Evidence from a new Index of Globalization, Applied Economics 38, 10, 1091-1110.

11. Easterly, W. (2008). Globalization. The New Palgrave Dictionary of Economics. Second Edition. The New Palgrave Dictionary of Economics Online. Retrieved February 10, 2012, from http://www.dictionaryofeconomics.com/article?id=pde2008_G000178.

12. European Bank for Reconstruction and Development. (2010). Retrieved February 29, 2012, from EBRD: http://www.ebrd.com/russian/pages/research/analysis/impact.shtml.

13. Feige, E. L. (1991). Perestroika and Ruble Convertibility. Retrieved February 02, 2012, from http://www.cato.org/pubs/journal/cj10n3/cj10n3-2.pdf.

14. Filatotchev, I., Mickiewicz, T. (2006). Private Benefits of Control and Debt Financing. Corporate Governance and Finance in Poland and Russia. Houndmills: Palgrave Macmillan.

15. Gylys, P. (2008). Ekonomika antiekonomika ir globalizacija. Monografija. Vilnius: Lithuania.

16. Grižas, A. (2006). Globaliniai ekonominiai procesai. -Ekonomikos mokymo centras.Vilnius: Lithuania.

17. Guillen, M. (2000). Is Globalization Civilizing, Destructive or Feeble? A Critic of Five Key Debates in the SocialScience Literature. Anual Review of Sociology, 27, 5.

18. Havrylyshyn, O. (1999). Determinants of Growth in Transition Countries. Retrieved February 02, 2012, from http://www.imf.org/external/pubs/ft/fandd/1999/06/havrylys.htm.

19. Held, D. ir kt. (2002). Globaliniai pokyčiai: politika, ekonomika, kultūra. Vilnius: Margi raštai.

20. Infoplease. All the KnowledgeYou Need. (2012). Most Widely Spoken Languages in the World. Retrieved February 03, 2012, from http://www.infoplease.com/ipa/A0775272.html.

21. Yip, G. S. (1989). Total Global Strategy. In a Word of Nations? Sloan Management rewiew, 31, 3.

22. Jatuliavičinė, G., Kučinskienè, M. (2006). Globalization Drivers and their Impact on Lithuanian Economic Growth and Development. Ekonomika, 73, 24-29.

23. Kilijoniene, A., Simanaviciene, Z., \& Simanavicius, A. (2010). The Evaluation of Social and Economic Development of the Region. Inzinerine Ekonomika-Engineering Economics, 21(1), 68-79.

24. Kirtiklis, K. (2005). Apie du globalizacijos veidus (I). Retrieved February 02, 2012, from http://www.bernardinai.lt/straipsnis/2005-08-12-kestas-kirtiklis-apie-du-globalizacijos-veidus-i/5873.

25. Klinger, M. (2010). Globalization Nerds come of Age. Multilingual, 5, 2, 12-24.

26. Kutschker, M., Schmid, S. (2004). International Management 3. Oldenbourg, München, Wien.

27. Kuzmickas, B. (2004). Šiuolaikinè filosofija: globalizacijos amžius. Monografija. Vilnius.

28. Lakstutiene, A., Breiteryte, A., \& Rumsaite, D. (2009). Stress Testing of Credit Risk Lithuania Banks under Simulated Economical Crisis Environment Conditions. Inzinerine Ekonomika-Engineering Economics(5), 15-24.

29. Lechner, F., Boli. J. (2004). The Globalization Reader. Blackwell Publishing LTD.

30. Legrain, Ph. (2006). The Truth about Globalization. Paper presented at the 2006 Conference: How can Lithuania survive on the Global Market? Vilnius, March 2-3.

31. Leichteris, E., Stumbryte, G. (2008). Lietuvos mokslo tarptautiškumas. Pagrindinè ataskaita. Vilnius.

32. Munck, R. (2010). Marxism and Nationalism in the Era of Globalization. Capital and Class, 43, 1, 11-15.

33. Najam, A. ir kt. (2007). Environment and Globalization: Five Propositions. Canada: International Institute of Sustainable Development. Retrieved February $\quad 04, \quad$ 2012, from http://www.iisd.org/pdf/2007/trade_environment_globalization.pdf. 
34. OECD (2005). OECD Handbook on Economic Globalization Indicators. Retrieved February 10, 2012, from http://www.oecd.org/document/44/0,3343,en_2649_34443.html.

35. Ohmae, K. (2000). The End of the Nation State. The Globalization Reader. Blackwell publishers: London.

36. Pugačiauskas, V. (2000). Globalizacija ir Lietuvos ekonominè politika. Retrieved February 02, 2012, from http://www.geocities.com/vykintas/m2mpa.html.

37. Ritzer, G. (2010). Globalization: a Basic Text. Willey-Blackwell: London.

38. Sachs, J. (1998). Unlocking the Mysteries of Globalization. Foreign Policy, 14, 8, 9-14.

39. Snieška, V. Research into International Competitiveness in 2000-2008 //Engineering Economics, 2008, No 4 (59).;

40. Snieška, V., Drakšaitè, A. The Role of Knowledge Process Outsourcing in Creating National Competitiveness in Global Economy. //Engineering Economics, 2007, No 3 (53);

41. Startienè G., Trimonis K. (2009). The size of non-observed economy. Economics \& Management, $2009,976-983$.

42. Stiglitz, J. (2002). Globalization and its Discontents. London: Penguin Books LTD.

43. Stonehouse, G. ir kt. (2000). Global and Transnational Business: Strategy and Management. Chichester: John Wiley and Sons.

44. Wikipedia, the Free Encyclopedia. (2012). List of Languages by Number of Native Speakers. Retrieved February 04, 2012, from http://en.wikipedia.org/wiki/List_of_languages_by_number_of_native_speakers.

45. Wikipedia, the Free Encyclopedia. (2012). Transition Economie. Retrieved February 10, 2012, from http://en.wikipedia.org/-wiki/Transition_economies.

46. Wolf, Ch. (2001). Globalization: Less than Meets the Eye. Straddling Economics and Politics. Cross-cutting Issues in Asia, United States, and the Global Economy. Retrieved February 04, 2012, from www.rand.org/pubs/monograph_reports/2006/MR1571.pdf.

47. Zedillo, E. (2008). The Future of Globalization: Explosions in Light of Turbulence. New York: Roughton. 